\title{
PENGARUH SIKAP KERJA, KEMAMPUAN DIRI DAN STRES KERJA TERHADAP KINERJA PEGAWAI DINAS PEKERJAAN UMUM DAN PENATAAN RUANG KOTA SIBOLGA
}

\author{
${ }^{1}$ Abdul Rahman Lubis, ${ }^{2}$ Falexius, ${ }^{3}$ Asmar Zunawi Harahap, ${ }^{4}$ Plenning Dalf. T., ${ }^{5}$ Abdul Kawi Siregar \\ ${ }_{1,2,3,4,5}$ Universitas Islam Sumatera Utara \\ 12abdul.lbs@gmail.com, ${ }^{2}$ falexius.mm@gmail.com, ${ }^{3}$ asmar.zunawi@ gmail.com, ${ }_{5}^{4}$ plenning.dalf@gmail.com, \\ 5abdulkawi.srg@gmail.com
}

\begin{abstract}
Problem of this study is how influence of job attitude on performance. How influence of self ability on performance. How influence of job stress on performance. How influence job attitude, self ability and job stress on performance. The purpose of this study to determine the effect of job attitude on performance. Determine the effect of self ability on performance. Determine the effect of job stress on performance. Determine the effect of job attitude, self ability and job stress on performance. Sample in the study is 60 employee. Data analysis techniques used in this study is descriptive analyze and multiple linear regression analysis. The results of the study indicate job attitude variable has a positive and significant effect on performance. Self ability variable has a positive and significant effect on performance. Job stress variable has a positive and no significant effect on performance. Job attitude, self ability and job stress variable has a positive and significant effect on performance.
\end{abstract}

Keywords : Job attitude, Selfability, Job stress, Performance.

ABSTRAK : Rumusan masalah penelitian ini adalah bagaimana pengaruh sikap kerja terhadap kinerja. Bagaimana pengaruh kemampuan diri terhadap kinerja. Bagaimana pengaruh stres kerja terhadap kinerja. Bagaimana pengaruh sikap kerja, kemampuan diri, dan stres kerja terhadap kinerja. Tujuan penelitian ini adalah untuk mengetahui pengaruh sikap kerja terhadap kinerja. Untuk mengetahui pengaruh kemampuan diri terhadap kinerja. Untuk mengetahui pengaruh stres kerja terhadap kinerja. Untuk mengetahui pengaruh sikap kerja, kemampuan diri dan stres kerja terhadap kinerja. Sampel dalam penelitian ini berjumlah 60 orang. Teknik analisis data yang digunakan dalam penelitian ini adalah analisis deskriptif dan analisis regresi linier berganda.

Hasil penelitian ini menjelaskan bahwa variabel sikap kerja berpengaruh positif dan signifikan terhadap kinerja. Variabel kemampuan diri berpengaruh positif dan signifikan terhadap kinerja. Variabel stres kerja berpengaruh positif dan tidak signifikan terhadap kinerja. Variabel sikap kerja, kemampuan diri dan stres kerja berpengaruh positif dan signifikan terhadap kinerja guru.

Kata kunci : Sikap kerja, Kemampuan diri, Stres kerja, Kinerja

\section{Pendahuluan}

Dinas Pekerjaan Umum Dan Penataan Ruang Kota Sibolga merupakan instansi yang berkedudukan sebagai unsur pelaksana teknis Otonomi Dan Penataan Ruang di bidang pekerjaan umum yang dipimpin oleh seorang Kepala Dinas yang berada dibawah dan bertanggungjawab kepada Walikota melalui Sekretaris Dan Penataan Ruang dengan tugas pokok melaksanakan sebagian urusan di bidang pekerjaan umum dan penataan ruang.

Dinas Pekerjaan Umum Dan Penataan Ruang Kota Sibolga, dalam mencapai tujuannya tidak terlepas dari peran serta setiap individu yang ada di instansi tersebut. Pegawai memainkan peranan yang sangat penting dalam mencapai keberhasilan instansi. Seberapa baik seorang pemimpin mengelola kinerja bawahannya akan secara langsung mempengaruhi kinerja individu, unit kerja dan organisasi secara keseluruhan.

Berdasarkan survei awal yang peneliti lakukan di Dinas Pekerjaan Umum dan Penataan Ruang Kota Sibolga, dapat penulis kemukakan variabel pertama yang mempengaruhi kinerja pegawai adalah sikap 
kerja. Menurut Ivancevich (2011:88), sikap kerja merupakan keadaan mental yang dipelajari dan diorganisasikan melalui pengalaman, menghasilkan pengaruh spesifik pada respons seseorang terhadap orang lain, objek, dan situasi yang berhubungan. Teori Roe (1999:116), menyatakan bahwa orang mencari kesesuaian antara keyakinan dan perasaan mereka terhadap objek dan menyatakan bahwa modifikasi sikap dapat dilakukan dengan mengubah sisi perasaan atau keyakinan tersebut, teori tersebut berpendapat bahwa kognisi, afeksi dan perilaku menentukan sikap dan bahwa sikap pun pada akhirnya menentukan kognisis, afeksi dan perilaku.

Penelitian terdahulu yang menjelaskan bahwa sikap kerja berpengaruh atau tidak berpengaruh terhadap kinerja pegawai, pertama penelitian dari Noviansyah (2011) menguji tentang pengaruh sikap kerja terhadap kinerja, kepuasan kerja, dan komitmen organisasi pada 65 staf PT. Perkebunan Minanga Ogan Baturaja. Hasil penelitian menjelaskan bahwa bahwa sikap kerja memiliki pengaruh positif tetapi tidak signifikan terhadap kinerja. Kedua penelitian dari Liao (2012), menguji tentang work values, work attitudes and job performance of Green Energy Industry Employee in Taiwan pada 485 pegawai dan direktur dari 48 organisasi green energy, hasil penelitian menjelaskan bahwa sikap kerja tidak berpengaruh terhadap kinerja pegawai.

Berdasarkan hasil penelitian dari Noviansyah (2011) dan Liao (2012), yang menguji pengaruh sikap kerja terhadap kinerja mempunyai hasil yang berbeda, oleh karena itu perlu kiranya dilakukan penelitian lagi untuk memperjelas hubungan kausal antara sikap kerja terhadap kinerja pegawai di Dinas Pekerjaan Umum Dan Penataan Ruang Kota Sibolga.

Variabel kedua yang mempengaruhi kinerja pegawai Dinas Pekerjaan Umum Dan Penataan Ruang Kota Sibolga adalah kemampuan diri. Menurut Robbins (2011:114) kemampuan adalah kapasitas individu untuk melakukan beragam tugas dalam suatu pekerjaan. Umumnya kapasitas individu dipengaruhi oleh kontribusi pengetahuan (knowledge), ketrampilan (skills), dan sikap (attitude) yang tertanam didalam pikiran yang berasal dari dalam diri sendiri, orang tua, pegawai dan lingkungan organisasi. Pada dasarnya kinerja dari seseorang merupakan hal yang bersifat individu, karena masing-masing individu memiliki tingkat kemampuan yang berbeda. Cascio (2012:221) mengemukakan bahwa kemampuan mental, intelegensi emosi, dan tacit knowledge dapat membantu membedakan pegawai yang berkinerja tinggi dengan pegawai yang berkinerja rendah.

Penelitian terdahulu yang menjelaskan bahwa kemampuan diri atau kompetensi berpengaruh atau tidak berpengaruh terhadap kinerja pegawai, pertama penelitian dari Yuliandi (2014), dengan sampel 100 orang pegawai PPAT, dengan hasil penelitian menjelaskan bahwa kompetensi, pengetahuan, ambiguitas peran berpengaruh signifikan terhadap kinerja pegawai. Kedua Setyaningdyah (2013), dengan sampel 232 orang pegawai dari 58 organisasi REI di Jakarta Pusat, meneliti tentang pengaruh kompetensi SDM, komitmen organisasi dan kepemimpinan transaksional terhadap disiplin kerja, kepuasan kerja, dan kinerja pegawai, hasil penelitian menjelaskan bahwa kompetensi SDM, komitmen organisasisi dan kepemimpinan transaksional berpengaruh signifikan terhadap kepuasan kerja. Kompetensi SDM, komitmen organisasi dan kepuasan kerja berpengaruh signifikan terhadap disiplin kerja. Komitmen organisasi, kepemimpinan transaksional dan disiplin kerja berpengaruh signifikan terhadap kinerja pegawai, akan tetapi kepemimpinan transaksional tidak berpengaruh terhadap disiplin kerja, kepuasan kerja tidak berpengaruh terhadap kinerja pegawai, dan kompetensi SDM tidak berpengaruh terhadap kinerja pegawai.

Berdasarkan hasil penelitian dari Yuliandi (2014) dan Setyaningdyah (2013), yang menguji pengaruh kemampuan diri terhadap kinerja mempunyai hasil yang berbeda, oleh karena itu perlu kiranya dilakukan penelitian lagi untuk memperjelas hubungan kausal antara kemampuan diri terhadap kinerja di Dinas Pekerjaan Umum Dan Penataan Ruang Kota Sibolga.

Variabel ketiga yang teridentifikasi mempengaruhi kinerja pegawai Dinas Pekerjaan Umum Dan Penataan Ruang Kota Sibolga adalah stres kerja. Menurut Robbins (2011:43) menjelaskan stres kerja adalah kondisi yang muncul dari interaksi antara pegawai dengan pekerjaan serta dikarakteristikkan oleh perubahan manusia yang memaksa mereka untuk menyimpang dari fungsi normal mereka. Gejala stres kerja ini dapat dilihat antara lain emosi tidak stabil, perasaan tidak tenang, suka menyendiri, sulit 
tidur, merokok yang berlebihan, tidak bisa rileks, cemas, tegang, gugup, tekanan darah meningkat, dan mengalami gangguan pencernaan. Stres kerja yang dialami oleh pegawai akan membawa dampak negatif terhadap motivasi kerja, artinya pegawai yang memiliki tingkat stres kerja tinggi cendrung memiliki kinerja yang rendah dan pada akhirnya berdampak penurunan kinerja pegawai tersebut. Untuk dapat mengungkap fenomena tentang stres kerja pegawai Dinas Pekerjaan Umum Dan Penataan Ruang Kota Sibolga, dilakukan pengamatan dengan cara wawancara secara lisan terhadap 10 orang pegawai yang pernah tidak masuk kerja karena sakit. Dari hasil wawancara tersebut penulis menemukan kebanyakan dari mereka yang sakit disebabkan karena gangguan pencernaan, sulit tidur dan tekanan darah tinggi, dimana hal-hal tersebut merupakan gejala seseorang mengalami stres kerja.

\subsection{Batasan Masalah}

Berdasarkan pada uraian di atas, banyak faktor yang teridentifikasi terkait pada variabel penelitian. Oleh karena itu peneliti membatasi permasalahan dalam penelitian ini hanya pada masalah sikap kerja, kemampuan diri dan stres kerja serta kinerja pegawai.

\subsection{Hioptesis}

Berdasarkan uraian teoretis, penelitian terdahulu dan kerangka konseptual yang telah dikemukakan di atas, maka dapat ditarik hipotesis penelitian ini sebagai berikut:

a. Sikap kerja berpengaruh positif dan signifikan terhadap kinerja pegawai Dinas Pekerjaan Umum Dan Penataan Ruang Kota Sibolga.

b. Kemampuan diri berpengaruh positif dan signifikan terhadap kinerja pegawai Dinas Pekerjaan Umum Dan Penataan Ruang Kota Sibolga.

c. Stres kerja berpengaruh negatif dan tidak signifikan terhadap kinerja pegawai Dinas Pekerjaan Umum Dan Penataan Ruang Kota Sibolga.

d. Sikap kerja, kemampuan diri dan stres kerja berpengaruh positif dan signifikan terhadap kinerja pegawai Dinas Pekerjaan Umum Dan Penataan Ruang Kota Sibolga.

\subsection{Tujuan Penelitian}

Tujuan dari penelitian ini adalah :

1. Untuk mengetahui pengaruh sikap kerja terhadap kinerja pegawai Dinas Pekerjaan Umum Dan Penataan Ruang Kota Sibolga.

2. Untuk mengetahui pengaruh kemampuan diri terhadap kinerja pegawai Dinas Pekerjaan Umum Dan Penataan Ruang Kota Sibolga.

3. Untuk mengetahui pengaruh stres kerja terhadap kinerja pegawai Dinas Pekerjaan Umum Dan Penataan Ruang Kota Sibolga.

4. Untuk mengetahui pengaruh sikap kerja, kemampuan diri dan stres kerja terhadap kinerja pegawai Dinas Pekerjaan Umum Dan Penataan Ruang Kota Sibolga.

\section{Metode Penelitian \\ 2.1. Populasi}

Menurut Sugiyono (2009:90), populasi adalah wilayah generasi yang terdiri dari atas objek/subjek yang mempunyai kualitas dan karakteristik tertentu yang disajikan oleh peneliti untuk dipelajari dan kemudian ditarik kesimpulannya. Berdasarkan defenisi tersebut, maka populasi dalam penelitian ini adalah pegawai Dinas Pekerjaan Umum Dan Penataan Ruang Kota Sibolga yang berjumlah 60 orang.

\subsection{Sampel}

Menurut Sugiyono (2009:93), sampel adalah elemen-elemen populasi yang dipilih atas dasar kemampuan mewakilinya. Untuk menjadi pedoman jika subjeknya atau populasinya kurang dari 100, maka lebih baik diambil semua sebagai sampel, sehingga penelitiannya merupakan penelitian populasi. Selanjutnya jika jumlah subjeknya atau populasinya besar atau lebih dari 100, maka dapat diambil persentasenya. Dengan teknik penarikan sampel secara total sampling, maka sampel dalam penelitian ini seluruh populasi yaitu 60 orang pegawai Dinas Pekerjaan Umum Dan Penataan Ruang Kota Sibolga. 
Tabel 1. Kerangka Sampel Pegawai Berdasarkan Bagian

\begin{tabular}{|c|l|c|}
\hline No & \multicolumn{1}{|c|}{ Keterangan } & Jumlah (Orang) \\
\hline 1 & $\begin{array}{l}\text { Bagian Umum, Kepegawaian dan } \\
\text { Perlengkapan }\end{array}$ & 9 \\
\hline 2 & Bagian Program dan Keuangan & 9 \\
\hline 3 & Bidang Bina Marga & 15 \\
\hline 4 & Bidang Cipta Karya & 8 \\
\hline 5 & Bidang SDA, PLP dan Air Minum & 12 \\
\hline 6 & Bidang Penataan Ruang dan Pertanahan & 5 \\
\hline 7 & UPTD Pengelolaan Air Limbah & 2 \\
\hline \multicolumn{2}{|c|}{ Total } & 60 \\
\hline
\end{tabular}

Sumber : Dinas Pekerjaan Umum Dan Penataan Ruang Kota Sibolga, 2020

\subsection{Uji Normalitas}

Menurut Sugiyono (2014:144) pengertian dari uji normalitas adalah untuk menguji apakah nilai residual yang dihasilkan dari regresi terdistribusi secara normal atau tidak. Model regresi yang baik adalah yang memiliki nilai residual yang terdistribusi normal. Untuk mengetahui bentuk distribusi data, bisa dilakukan dengan grafik distribusi dan analisis statistik. Pengujian dengan distribusi dilakukan dengan melihat grafik histogram yang membandingkan antara dua observasi dengan distribusi yang mendekati distribusi normal. Distribusi normal akan membentuk satu garis lurus diagonal dan ploating data residual akan dibandingkan dengan garis diagonal. Jika distribusi atau residual normal, maka garis yang menggambarkan data yang sesungguhnya akan mengikuti garis diagonalnya. Uji normalitas dengan grafik dapat dilakukan dengan program SPSS dengan analisis grafik Normal Probability Plot

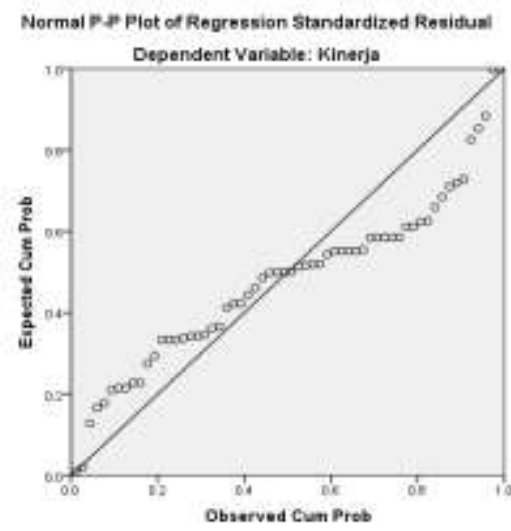

Gambar 1. Uji normalitas data

Berdasarkan gambar 1, diatas terlihat titiktitik dari ploating data residual berada di garis diagonal, hal ini dapat disimpulkan data yang diuji berdistribusi normal.

\subsection{Uji Multikolinearitas}

Salah satu asumsi dari model regresi linier bahwa tidak terjadi korelasi yang signifikan antara variabel bebasnya. Untuk menguji hal tersebut maka diperlukan suatu uji yang disebut uji multikolinieritas. Menurut Sugiyono (2014:151) pengertian multikolinieritas adalah keadaan di mana pada model regresi ditemukan adanya korelasi yang sempurna atau mendekati sempurna antar variabel independen. Pada regresi yang baik seharusnya tidak terjadi korelasi yang sempurna atau mendekati sempurna diantara variabel bebas. Uji multikolinieritas adalah untuk melihat ada atau tidaknya korelasi yang tinggi antara variabelvariabel bebasnya, maka hubungan antara variabel bebas terhadap variabel terikatnya menjadi terganggu. Jika terdapat korelasi yang kuat dimana sesama variabel independen maka konsekuensinya adalah :

a. Koefisien-koefisien regresi menjadi tidak dapat ditaksir

b. Nilai standar error setiap koefisien regresi menjadi tidak terhingga.

Dengan demikian, semakin besar korelasi diantara sesama variabel independen maka tingkat kesalahan dari koefisien regresi semakin besar yang dapat mengakibatkan standar error semakin besar pula. Cara yang digunakan untuk mendeteksi ada tidaknya multikolinieritas adalah dengan melihat besarnya nilai Variance Inflation Factor (VIF). Jika VIF dibawah 10 dan Tolerance Value diatas 0,1 maka tidak terjadi multikolinieritas.

Tabel 2. Uji multikolinieritas

\begin{tabular}{|l|c|c|}
\hline \multirow{2}{*}{ Variabel } & \multicolumn{2}{|c|}{ Collinearity Statistics } \\
\cline { 2 - 3 } & Tolerance & VIF \\
\hline Sikap kerja & 0.799 & 1.252 \\
\hline Kemampuan diri & 0.788 & 1.269 \\
\hline Stres kerja & 0.968 & 1.033 \\
\hline
\end{tabular}


Berdasarkan Tabel 2, diatas diperoleh nilai Tolerance Value diatas 0.1 yaitu $0.799,0.788$, 0.968; hal ini menunjukan adanya korelasi yang cukup tinggi/kuat antara sesama variabel bebas dan nilai Variance Inflantion Factorrs (VIF) sebesar 1.252, 1.269, 1.033, dimana nilai VIF dari ketiga varibel bebas lebih kecil dari 10 dan dapat disimpulkan tidak terdapat multikolinieritas diantara ketiga variabel bebas yang diuji dalam penelitian ini.

\subsection{Uji Autokorelasi}

Uji autokorelasi merupakan pengujian dimana variabel dependen tidak berkorelasi dengan nilai variabel itu sendiri, baik nilai periode sebelumnya maupun nilai periode sesudahnya. Menurut Sugiyono (2014:172) pengertian dari autokorelasi adalah keadaan di mana pada model regresi ada korelasi antara residual pada periode tertentu $t$ dengan residual pada periode sebelumnya ( $\mathrm{t}-1)$, model regresi yang baik adalah yang tidak terdapat masalah autokorelasi. Metode pengujian menggunakan uji Durbin-Watson (DW-test). Salah satu ukuran dalam menentukan ada tidaknya masalah autokorelasi dengan uji Durbin-Watson (DW) dengan ketentuan sebagai berikut :

3. $1.65<\mathrm{DW}<2.35$ tidak terjadi autokorelasi

4. 1.21. $<\mathrm{DW}<1.65$ atau $2.35<\mathrm{DW}<2.79$ tidak dapat disimpulkan.

5. $\mathrm{DW}<1.21$ atau $\mathrm{DW}>2.79$ terjadi autokorelasi.

Tabel 3. Uji Autokorelasi

\begin{tabular}{|l|r|r|r|r|r|r|}
\hline & \multicolumn{5}{|c|}{ Change Statistics } & \multirow{2}{*}{$\begin{array}{c}\text { Durbin- } \\
\text { Watson }\end{array}$} \\
\cline { 2 - 6 } Model & $\begin{array}{c}\text { R Square } \\
\text { Change }\end{array}$ & F Change & df1 & df2 & $\begin{array}{c}\text { Sig. F } \\
\text { Change }\end{array}$ & \\
\hline 1 & .742 & 53.688 & 3 & 56 & .000 & 2.132 \\
\hline
\end{tabular}

Sumber : Hasil pengolahan data, 2020

Berdasarkan Tabel 3, di atas diperoleh nilai Durbin-Watson (DW) sebesar 2.132, nilai ini berada pada kisaran $1.65<\mathrm{DW}<2.35$, maka dapat disimpulkan bahwa tidak terjadi autokorelasi pada model regresi yang diuji dalam penelitian ini.

\subsection{Uji Heteroskedastisitas}

Uji heteroskedastisitas bertujuan untuk menguji apakah dalam model regresi terjadi ketidaksamaan variance dari residual satu pengamatan ke pengamatan yang lainnya. Gejala variance yang tidak sama ini disebut dengan heteroskedastisitas, sedangkan adanya gejala residual yang sama dari satu pengamatan ke pengamatan lain disebut dengan homokedastisitas. Menurut Sugiyono (2014:158) pengertian dari heteroskedastisitas adalah dimana dalam model regresi tejadi ketidaksamaan varian dari residual pada suatu pengamatan ke pengamatan yang lain. Model regresi yang baik adalah tidak terjadi heteroskedastisitas. Berbagai macam uji heteroskedastisitas yaitu dengan uji glejser, melihat pola titik-titik pada scatterplots regresi, atau uji koefisien korelasi spearman's.

Uji heteroskedastisitas dapat dilakukan dengan menggunakan grafik scatterplot antara nilai variabel terikat (ZSPRED) dengan residualnya (SRESID), dimana sumbu $X$ adalah yang diprediksi dan sumbu $\mathrm{Y}$ adalah residual.
Dasar pengambilan keputusan yang dapat diambil adalah sebagai berikut :

a. Jika pola tertentu seperti titik-titik yang ada membentuk suatu pola yang teratur (bergelombang, melebar kemudian menyempit) maka telah terjadi heteroskedastisitas.

b. Jika tidak ada yang jelas serta titik-titik menyebar diatas dan dibawah angka nol pada sumbu Y maka tidak terjadi heteroskedastisitas

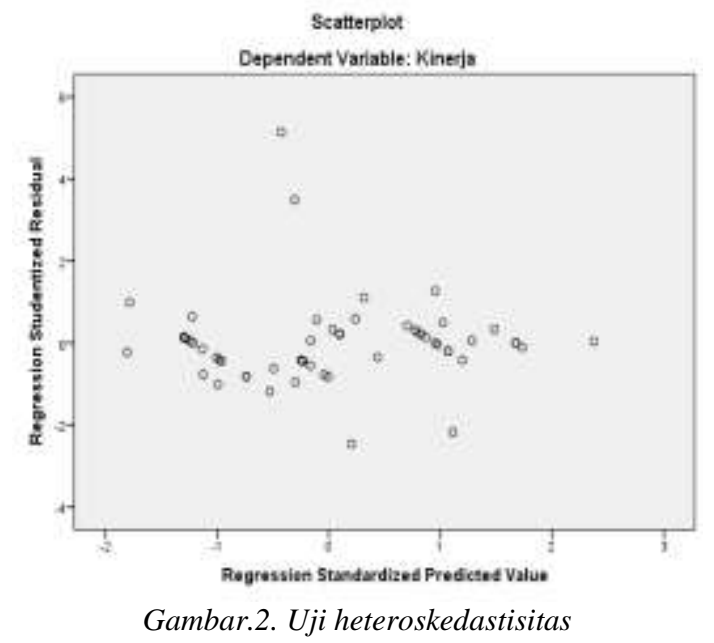

Berdasarkan gambar 2, diatas, menunjukkan titik-titik yang menyebar, sehingga dapat disimpulkan tidak terjadi heteroskedastisitas di data penelitian ini. 
3. Evaluasi Data dan Pembahasan

3.1. Hasil Regresi Linear Berganda

Analisis regresi linier berganda dalam penelitian ini dapat dilihat dari persamaan

Tabel 4. Analisis regresi linier berganda

\begin{tabular}{|l|r|r|r|r|r|}
\hline \multirow{2}{*}{ Model } & \multicolumn{2}{|c|}{$\begin{array}{c}\text { Unstandardized } \\
\text { Coefficients }\end{array}$} & $\begin{array}{c}\text { Standardized } \\
\text { Coefficients } \\
\text { Beta }\end{array}$ & \multirow{2}{*}{$\mathrm{t}$} & \multirow{2}{*}{ Sig. } \\
\cline { 2 - 3 } & \multicolumn{1}{c|}{$\mathrm{B}$} & Std. Error & & \\
\hline (Constant) & -.849 & 3.715 & & -.228 & .820 \\
\hline Sikap kerja & .228 & .071 & .242 & 3.191 & .002 \\
\hline Kemampuan diri & .705 & .078 & .694 & 9.077 & .000 \\
\hline Stres kerja & .088 & .049 & .123 & 1.788 & .079 \\
\hline
\end{tabular}

Sumber : Hasil pengolahan data, 2020

Berdasarkan Tabel 4, diatas dapat dibuat persamaan regresi dalam penelitian ini sebagai berikut::

$$
\begin{gathered}
Y=-0.849+0.228 X_{1}+0.705 X_{2}+ \\
0.088 X_{3}+e
\end{gathered}
$$

Dari persamaan regresi linier berganda di atas dapat dijelaskan :

1) Nilai kinerja pegawai Dinas Pekerjaan Umum dan Penataan Ruang Kota Sibolga sebesar -0.849 , dengan ketentuan nilai dari variabel bebas $\left(\mathrm{X}_{1}, \mathrm{X}_{2}\right.$, dan $\left.\mathrm{X}_{3}\right)$ diabaikan.

2) Nilai koefisien regresi $X_{1}$ (sikap kerja) mempunyai nilai positif yaitu 0.228 , hal ini menunjukkan bahwa variabel sikap kerja mempunyai pengaruh positif terhadap kinerja pegawai Dinas Pekerjaan Umum dan Penataan Ruang Kota Sibolga.

3) Nilai koefisien regresi $X_{2}$ (kemampuan diri) mempunyai nilai positif yaitu 0.705 , hal ini menunjukkan bahwa variabel kemampuan regresinya, dan dari hasil pengolahan data diperoleh hasil berikut ini :

Tabel. 5, Pengaruh sikap kerja terhadap kinerja

\begin{tabular}{|l|r|r|r|r|r|}
\hline \multirow{2}{*}{ Model } & \multicolumn{2}{|c|}{$\begin{array}{c}\text { Unstandardized } \\
\text { Coefficients }\end{array}$} & $\begin{array}{c}\text { Standardized } \\
\text { Coefficients } \\
\text { Beta }\end{array}$ & $\mathrm{t}$ & \multirow{2}{*}{ Sig. } \\
\cline { 2 - 3 } & \multicolumn{1}{|c|}{$\mathrm{B}$} & \multicolumn{1}{|c|}{ Std. Error } & & \\
\hline (Constant) & -.849 & 3.715 & & -.228 & .820 \\
\hline Sikap kerja & .228 & .071 & .242 & 3.191 & .002 \\
\hline
\end{tabular}

a. Dependent Variable : Kinerja

Dari Tabel 5, diatas diperoleh nilai $t_{\text {hitung }}$ sebesar 3.205. Penelitian ini menggunakan taraf signifikansi $(\alpha: 0.05)$ dan Derajat Kebebasan (DK) dengan ketentuan DK $=\mathrm{n}-2$, atau $60-2$ $=58$. Dengan ketentuan tersebut, diperoleh nilai $\mathrm{t}_{\text {tabel }}$ sebesar 2.002. Dengan kriteria hipotesis sebagai berikut :

Jika nilai $t_{\text {hitung }}>t_{\text {tabel }}$, maka hipotesis penelitian diterima.

Jika nilai $t_{\text {hitung }}<t_{\text {tabel }}$, maka hipotesis penelitian ditolak.

Dari hasil pengolahan data diperoleh nilai $t_{\text {hitung }}>t_{\text {tabel }}(3.191>2.002)$ dan nilai signifikasi diri mempunyai pengaruh positif terhadap kinerja pegawai Dinas Pekerjaan Umum dan Penataan Ruang Kota Sibolga.

4) Nilai koefisien regresi $X_{3}$ (stres kerja) mempunyai nilai positif yaitu 0.088 , hal ini menunjukkan bahwa variabel stres kerja mempunyai pengaruh positif terhadap kinerja pegawai Dinas Pekerjaan Umum dan Penataan Ruang Kota Sibolga.

\subsection{Pengaruh Sikap Kerja Terhadap Kinerja Pegawai Dinas Pekerjaan Umum dan Penataan Ruang Kota Sibolga.}

Untuk mengetahui pengaruh sikap kerja terhadap kinerja pegawai Dinas Pekerjaan Umum dan Penataan Ruang Kota Sibolga digunakan uji-t, sedangkan untuk melihat besarnya pengaruh digunakan nilai Beta atau Standardized Coefficient Beta. 
terhadap kinerja, dan tidak sesuai dengan hasil penelitian Liao (2012). Artinya jika sikap kerja pegawai dalam bekerja menunjukkan sikap yang baik dan jujur, maka kinerja pegawai akan naik, begitu juga sebaliknya jika sikap kerja pegawai dalam bekerja tidak baik dan jujur, maka kinerja pegawai Dinas Pekerjaan Umum dan Penataan Ruang Kota Sibolga tinggi juga akan turun.

\subsection{Pengaruh Kemampuan diri Terhadap Kinerja Pegawai Dinas Pekerjaan Umum dan Penataan Ruang Kota Sibolga.}

Untuk mengetahui pengaruh kemampuan diri terhadap kinerja pegawai Dinas Pekerjaan Umum dan Penataan Ruang Kota Sibolga digunakan uji-t, sedangkan untuk melihat besarnya pengaruh digunakan nilai Beta atau Standardized Coefficient Beta.

Tabel. 6, Pengaruh kemampuan diri terhadap kinerja

\begin{tabular}{|l|r|r|r|r|r|}
\hline \multirow{2}{*}{ Model } & \multicolumn{2}{|c|}{$\begin{array}{c}\text { Unstandardized } \\
\text { Coefficients }\end{array}$} & $\begin{array}{c}\text { Standardized } \\
\text { Coefficients } \\
\text { Beta }\end{array}$ & $\mathrm{t}$ & \multirow{2}{*}{ Sig. } \\
\cline { 2 - 3 } & \multicolumn{1}{|c|}{$\mathrm{B}$} & \multicolumn{1}{|c|}{ Std. Error } & & \\
\hline (Constant) & -.849 & 3.715 & & -.228 & .820 \\
\hline Kemampuan diri & .705 & .078 & .694 & 9.077 & .000 \\
\hline
\end{tabular}

Dari Tabel 6, diatas diperoleh nilai $\mathrm{t}_{\text {hitung }}$ sebesar 9.077. Penelitian ini menggunakan taraf signifikansi $(\alpha: 0.05)$ dan Derajat Kebebasan (DK) dengan ketentuan DK $=\mathrm{n}-2$, atau $60-2$ $=58$. Dengan ketentuan tersebut, diperoleh nilai $t_{\text {tabel }}$ sebesar 2.002. Dengan kriteria hipotesis sebagai berikut :

Jika nilai $t_{\text {hitung }}>t_{\text {tabel }}$, maka hipotesis penelitian diterima.

Jika nilai $\mathrm{t}_{\text {hitung }}<\mathrm{t}_{\text {tabel }}$, maka hipotesis penelitian ditolak.

Dari hasil pengolahan data diperoleh nilai $t_{\text {hitung }}>t_{\text {tabel }}(9.077>2.002)$ dan nilai signifikasi lebih kecil dari nilai $\alpha: 0.05$ yaitu $0.002<0.05$, sehingga hipotesis yang diajukan dalam penelitian ini diterima. Artinya variabel kemampuan diri secara partial berpengaruh positif dan signifikan terhadap kinerja pegawai Dinas Pekerjaan Umum dan Penataan Ruang Kota Sibolga. Besarnya pengaruh variabel kemampuan diri terhadap kinerja pegawai Dinas Pekerjaan Umum dan Penataan Ruang
Kota Sibolga sebesar 0.694 atau $69.40 \%$. Hasil penelitian ini sejalan dengan hasil penelitian dari Yuliandi (2014), dengan kesimpulan bahwa kemampuan diri berpengaruh positif dan signifikan terhadap kinerja, dan tidak sesuai dengan hasil penelitian dari dan Setyaningdyah (2013). Jadi pada saat atasan dapat memperhatikan bawahan dan memberikan contoh yang baik, maka kinerja pegawai akan naik, begitu juga sebaliknya atasan kurang perhatian ke bawahan, maka kinerja pegawai juga akan turun.

\subsection{Pengaruh Stres Kerja Terhadap Kinerja Pegawai Dinas Pekerjaan Umum dan Penataan Ruang Kota Sibolga. \\ Untuk mengetahui pengaruh stres kerja} terhadap kinerja pegawai Dinas Pekerjaan Umum dan Penataan Ruang Kota Sibolga digunakan uji-t, sedangkan untuk melihat besarnya pengaruh digunakan nilai Beta atau Standardized Coefficient Beta.

Tabel. 7, Pengaruh stres kerja terhadap kinerja

\begin{tabular}{|c|c|c|c|c|c|}
\hline \multirow[t]{2}{*}{ Model } & \multicolumn{2}{|c|}{$\begin{array}{c}\text { Unstandardized } \\
\text { Coefficients }\end{array}$} & \multirow{2}{*}{$\begin{array}{c}\text { Standardized } \\
\text { Coefficients } \\
\text { Beta }\end{array}$} & \multirow[t]{2}{*}{$\mathrm{t}$} & \multirow[t]{2}{*}{ Sig. } \\
\hline & $\mathrm{B}$ & Std. Error & & & \\
\hline (Constant) & -.849 & 3.715 & & -.228 & .820 \\
\hline Stres kerja & .088 & (049 & .123 & 1.788 & .079 \\
\hline
\end{tabular}

a. Dependent Variable : Kinerja

Dari Tabel 7 , diatas diperoleh nilai $\mathrm{t}_{\text {hitung }}$ sebesar 1.788. Penelitian ini menggunakan taraf signifikansi $(\alpha: 0.05)$ dan Derajat Kebebasan (DK) dengan ketentuan DK $=\mathrm{n}-2$, atau $60-2$ $=58$. Dengan ketentuan tersebut, diperoleh nilai $t_{\text {tabel }}$ sebesar 2.002. Dengan kriteria hipotesis sebagai berikut :

Jika nilai $t_{\text {hitung }}>t_{\text {tabel }}$, maka hipotesis penelitian diterima. 
Jika nilai $\mathrm{t}_{\text {hitung }}<\mathrm{t}_{\text {tabel }}$, maka hipotesis penelitian ditolak.

Dari hasil pengolahan data diperoleh nilai $t_{\text {hitung }}>t_{\text {tabel }}(1.788<2.002)$ dan nilai signifikasi lebih kecil dari nilai $\alpha: 0.05$ yaitu $0.079>0.05$, sehingga hipotesis yang diajukan dalam penelitian ini ditolak. Artinya variabel stres kerja secara partial berpengaruh positif dan tidak signifikan terhadap kinerja pegawai Dinas Pekerjaan Umum dan Penataan Ruang Kota Sibolga. Besarnya pengaruh variabel stres kerja terhadap kinerja pegawai Dinas Pekerjaan Umum dan Penataan Ruang Kota Sibolga sebesar 0.249 atau $24.90 \%$. Hasil penelitian ini tidak sejalan dengan hasil penelitian dari Nair, P.P dan Ganesh, S.S. (2016), dimana menarik kesimpulan bahwa stres kerja berpengaruh positif dan tidak signifikan terhadap kinerja.
Artinya jika stres pegawai dalam menyelesaikan suatu pekerjaan rendah, maka kinerja pegawai akan naik, begitu juga sebaliknya jika stres pegawai dalam menyelesaikan suatu pekerjaan tinggi, maka kinerja pegawai Dinas Pekerjaan Umum dan Penataan Ruang Kota Sibolga tinggi juga akan turun.

\subsection{Pengaruh Sikap Kerja, Kemampuan diri Dan Stres Kerja Terhadap Kinerja Pegawai Dinas Pekerjaan Umum dan Penataan Ruang Kota Sibolga.}

Untuk mengetahui pengaruh sikap kerja, kemampuan diri dan stres kerja terhadap kinerja pegawai Dinas Pekerjaan Umum dan Penataan Ruang Kota Sibolga digunakan uji-F.

Tabel 8. Pengaruh sikap kerja, kemampuan diri dan stres kerja terhadap kinerja

\begin{tabular}{|l|l|c|r|r|r|c|}
\hline Model & & $\begin{array}{c}\text { Sum of } \\
\text { Squares }\end{array}$ & \multicolumn{1}{c|}{ df } & $\begin{array}{c}\text { Mean } \\
\text { Square }\end{array}$ & \multicolumn{1}{c|}{ F } & \multicolumn{1}{c|}{ Sig. } \\
\hline \multirow{2}{*}{1} & Regression & 452.578 & 3 & 150.859 & 53.688 & $.000^{\mathrm{a}}$ \\
\cline { 2 - 7 } & Residual & 157.355 & 56 & 2.810 & & \\
\cline { 2 - 7 } & Total & 609.933 & 59 & & & \\
\hline
\end{tabular}

Dependent Variable : Kinerja

Sumber : Hasil pengolahan data, 2020

Dari Tabel 8,di atas diperoleh nilai $\mathrm{F}_{\text {hitung }}$ sebesar 51.292. Penelitian ini menggunakan taraf signifikansi $(\alpha: 0.05)$ dan Derajat Kebebasan (DK) dengan ketentuan numerator : jumlah variabel -1 atau $4-1=3$, dan jumlah sampel dikurang 4 atau $60-4=56$. Dengan ketentuan tersebut, diperoleh nilai $\mathrm{F}_{\text {tabel }}$ sebesar 2.77. Dengan kriteria pengujian hipotesis sebagai berikut :

Jika $\mathrm{F}_{\text {hitung }}>\mathrm{F}_{\text {tabel}}$, maka hipotesis penelitian diterima.

Jika $F_{\text {hitung }}<F_{\text {tabel }}$, maka hipotesis penelitian ditolak.

Dari hasil perhitungan diperoleh nilai $\mathrm{F}_{\text {hitung }}$ $>\mathrm{F}_{\text {tabel }}(53.688>2.77)$ dan nilai signifikasi 0.00 $<0.05$, sehingga hipotesis yang diajukan dalam penelitian ini diterima. Artinya variabel sikap kerja, kemampuan diri dan stres kerja secara simultan berpengaruh positif dan signifikan terhadap kinerja pegawai Dinas Pekerjaan Umum dan Penataan Ruang Kota Sibolga. Dengan demikian model regresi ini sudah layak dan benar dan dapat disimpulkan bahwa variabel sikap kerja, kemampuan diri dan stres kerja berpengaruh terhadap kinerja pegawai Dinas Pekerjaan Umum dan Penataan Ruang Kota Sibolga.

\section{3..6. Uji Determinan}

Uji determinan adalah untuk mengetahui seberapa besar pengaruh variabel sikap kerja, kemampuan diri dan stres kerja terhadap kinerja pegawai Dinas Pekerjaan Umum dan Penataan Ruang Kota Sibolga, dan dapat dilihat dari model summary, khususnya nilai Adjusted Rsquare.

Tabel 9. Model summary ${ }^{\mathrm{b}}$ pengaruh sikap kerja, kemampuan diri dan stres kerja terhadap kinerja

\begin{tabular}{|l|c|r|r|c|}
\hline Model & $R$ & $R$ Square & $\begin{array}{c}\text { Adjusted } R \\
\text { Square }\end{array}$ & $\begin{array}{c}\text { Std. Error of the } \\
\text { Estimate }\end{array}$ \\
\hline 1 & $.861^{\mathrm{a}}$ & .742 & .728 & 1.67628 \\
\hline
\end{tabular}

Dependent Variable : Kinerja 
Besarnya Tabel 9 diatas diperoleh nilai Adjusted Rsquare $\left(\mathrm{r}^{2}\right)$ sebesar 0.728. Nilai tersebut mempunyai maksud bahwa pengaruh variabel sikap kerja, kemampuan diri dan stres kerja terhadap kinerja pegawai Dinas Pekerjaan Umum dan Penataan Ruang Kota Sibolga sebesar $72.80 \%$, sedangkan sisanya sebesar $27.20 \%$ dipengaruhi oleh faktor-faktor lain yang tidak diteliti. Dengan kata lain variabel kinerja pegawai Dinas Pekerjaan Umum dan Penataan Ruang Kota Sibolga dapat diterangkan oleh variabel sikap kerja, kemampuan diri dan stres kerja sebesar $72.80 \%$, sedangkan sisanya sebesar $27.20 \%$ disebabkan oleh variabel-variabel lain yang tidak diteliti seperti lingkungan kerja, disiplin kerja, sikap kerja dan lain sebagainya.

\section{Kesimpulan}

Berdasarkan pada pembahasan pada bab sebelumnya, maka dapat ditarik kesimpulan dari penelitian ini sebagai berikut :

a. Variabel sikap kerja secara partial berpengaruh positif dan signifikan terhadap kinerja pegawai Dinas Pekerjaan Umum dan Penataan Ruang Kota Sibolga.

b. Variabel kemampuan diri secara partial berpengaruh positif dan signifikan terhadap kinerja pegawai Dinas Pekerjaan Umum dan Penataan Ruang Kota Sibolga.

c. Variabel stres kerja secara partial berpengaruh positif dan tidak signifikan terhadap kinerja pegawai Dinas Pekerjaan Umum dan Penataan Ruang Kota Sibolga.

d. Variabel sikap kerja, kemampuan diri dan stres kerja secara simultan berpengaruh positif dan signifikan terhadap kinerja pegawai Dinas Pekerjaan Umum dan Penataan Ruang Kota Sibolga.

\section{DAFTAR PUSTAKA}

Cascio, Wayne F.,( (2012) Managing Human Resources: Productivity, Quality of Work Life, Profits, edition, New York, McGraw Hill

Colquitt, J. A., LePine, J. A., and Wesson., (2009) Organizational Behavior: Improving Performance and Commitment in the Workplace, New York, McGraw Hill, pp. 37

Cross, T.M dan Lynch. R.R. (2012). Peniliaian dan Evaluasi Kinerja: Konsep dan Praktik. Jakarta. Penerbit Ghalia Indonesia

Dessler, Gary. (2011). Manajemen Sumber Daya Manusia (Jilid I). Jakarta : Indeks.
Gibson, James L., Ivancevich, John M., Donnely, James H., and Konopaske (2009) Organizations: Behavior, Structure, Processes, New York, McGraw Hill.

Hasibuan, Malayu S. P. (2012). Manajemen Sumber Daya Manusia. Edisi Revisi Jakarta: PT. Bumi Aksara.

Ivancevich, G., and Koropaske, D., (2011) Organizations: Behavior, Stucture, Process, Singapore, McGraw Hill Company

Ivancevich, John M., Konopaske, Robert., and Matteson, Michael T., (2011) Organizational Behavior and Management, $7^{\text {th }}$ edition, McGraw Hill, Alih Bahasa Gina Gania, Perilaku dan Manajemen Organisasi, Jilid 1, Edisi 7, Jakarta, Erlangga

Liao (2012), The impact of work values, work attitudes on job performance of Green Energy Industry Employee in Taiwan

Mangkunegara, Anwar, Prabu. (2009). Evaluasi Kinerja SDM, Cetakan 4, Bandung : Refika Aditama

Murphy, S. E., and Pirozzolo, F. J., (2012) Multi Journal ple Intelligences and Leadership, New Jersey, Lawrence Erlbaum Noviansyah dan Zunaidah (2011). Pengaruh sikap kerja dan motivasi kerja terhadap kinerja pegawai PT. Perkebunan Minanga Ogan Baturaja. Jurnal Manajemen dan Bisnis Sriwijaya Vol.9 No.18

Petty, Ricard E., Brinol, Pablo., dan Tormala, Zakary L., (2012) "Thought Confidence as a Determinant of Persuasion: The Self ValidationHypothesis", Journal of Personality and Social Psychology, pp. 722734

Riduwan. (2011). Skala Pengukuran VariabelVariabel Bandung : Alfabeta

Rivai, Veithzal dan Sagala, Ella Jauvani. (2009). Manajemen Sumber Daya Manusia Untuk Perusahaan : Dari Teori ke Praktek. Jakarta : PT. Rajagrafindo Persada

Robbins, Stephen P., dan Judge, Timothy A., (2012) Perilaku Organisasi, Terjemahan Edisi Dua Belas, Jakarta, Salemba Empat. (2009) Organizational Behavior, $13^{\text {th }}$ edition, New Jersey, Pearson Education, Upper Saddle River.

Robbins, Stephen P., and Coulter, Mary., (2011) Management, New Jersey, Pearson Prentice Hall, pp. 489

Samsudin, Sadili. (2009). Manajemen Sumber Daya Manusia. Bandung: CV. Pustaka Setia. 
Sedarmayanti. (2004). Good Governance (Kepemerintahan Yang Baik), Bandung : Mandar Maju

Sekaran, U., dan Bougie (2010), Research Methods for Busines. A Skill Building Approach. Fifth Edition. A John Wiley and Sons, Ltd, Publication.

Setyaningdyah Endang, Nimran Umar Kertahadi, Thoyib Armanu (2013). The Effects of Human Resource Competence Oragnizational Commitment and Transactioanl Leadership On Work Discipline, Job satisfaction and Employee's Performance. Interdisciplinary Journal of Contemporary Research in Business. Volume 5, No 4

Sink, R dan Tuttle, J.K. (2009). Evaluasi Kinerja. Jakarta: Indeks Kelompok Gramedia.

Slocum, Herriegel., (2009) "Principles of Organizational Behavior Tweith Edition". Canada South western

Stone, Raymond., (2005) Human Resource Management, Fifth Edition, Australia, John Wiley \& Sons
Sugiyono. (2009). Metode Penelitian Kuantitatif dan Kualitatif dan $R$ dan $D$. Bandung : Alfabeta

Taghavi, Safura., Ebrahimzadeh, Fariman., Bhramzadh, Hossein Ali., dan Masoumeh, Hosseini., (2014) "A Study of the Relationship Between Quality of Worklife and Performance Effectiveness of High School Teachers in Shirvan", International Journal of Academic Research in Business and Social Sciences, Vol. 4, No. 1, ISSN : 2222-6990

Thoha, Miftah. (2001). Birokrasi Indonesia Dalam Era Globalisasi, Pusdiklat Pegawai Depdiknas, Sawangan, Bogor.

Yuliandi (2014). Influence of Competency, knowledge and Role Ambiquity on Job performance and Implication for PPAT Performance. Journal of Economics and Sustainable Development. ISSN 2222-1700, ISSN 2222-2855 (Online), Vol 5 No 17

Zin, R. M., (2004) "Perception of Professional Engineers Toward Quality of Work Life and Organizational Commitment a Case Study", Gadjah Mada InternationalJournal of Business, 6(3), 323-262 